\title{
THE NEWLY OPENED ROCK CHURCH IN THE GROUND PART OF THE MONASTERY COMPLEX "THE BAPTISTERY” FROM THE IVANOVO ROCK-HEWN MONASTERIES
}

\author{
Evgeni Koev \\ "St. Cyril and St. Methodius" University of Veliko Tarnovo \\ Faculty of History, Department of Geography, Bulgaria \\ ev_koeff@abv.bg
}

\begin{abstract}
In another field study in the region of the Ivanovo rockhewn monasteries, led by Evgeni Koev, a rock-hewn church was found in the area of the Monastery Complex "The Baptistery". This specific site is a rockhewn temple which has a unique location at the ground level of the rock wreath. It has not been documented in previous studies of this area. The church has a carefully shaped and processed eastern half. There is a carved characteristic absid in eastern direction, replacing the holy throne, a prosthetic niche and a replica of the rock-hewn Vladish throne. For the first time, the rock-hewn church is mapped and described in detail, giving a specific interpretation of the time of its construction and use, as well as showing the specific purpose of the temple and the adjacent monastic cells. Baptistery

Keywords: Rock-hewn Church; Newly Discovered; Documented;
\end{abstract}

\section{НОВООТКРИТАТА СКААНА ЦЪРКВА В ПРИЗЕМНАТА ЧАСТ НА МАНАСТИРСКИЯ КОМПАЕКС „КРЪЩЕАНЯТА“ ОТ ИВАНОВСКИТЕ СКААНИ МАНАСТИРИ}

\author{
Евгени Коев \\ ВТУ „Св.Св. Кири^ и Методий“, Велико Търново, България \\ Факултет по история, катеАра „Географиия"
}

Резюме: При поредното теренното проучване в района на Ивановски скални манастири, рьководено от Евгени Коев, в района на манастирския комп^екс „Кръщелнята“ е открита непроучвана $А$ о този момент скална цьрква. Конкретният обект, преАставлява скалноизсечен храм с уникално разположение в приземното ниво на скалния венец. Същата не е документирана при досегашните изслеАвания на района. Цьрквата е с изключително старателно одрормена и обработена източна половина. Има изсечена характерна абсила в източна посока, заместваща светият престол, протезисна ниша и полобие на скално изсечен в^алишки трон. Скалната цьрква за пьрви пьт е картирана и описана обстойно, като се $а$ ава и своеобразна интерпретация за времето на нейното изграждане и използване, както и за специфричното предназначение на храма и прилежащите монашески килии. 


\section{Крьщелнята}

КАючови Ауми: Скална цьрква, новооткрита, Аокументирана,

Ивановските скални манастири са еАин от най-впечатляващите наскални културно-исторически комплекси свързани с разцвета на среАновековното ни православно наследство. Антропогенизираните окарстени, скални венци в района на местността "Писмената" предизвикват и представляват интерес за краеведи, учени и изследователи вече в продьлжение на повече от 140 гоАИни. ЕАни От найвиАните изслеАователи на Ивановските скални манастири / спореА някой от учените - цьркви, преАставляващи еАин общ манастирски комплекс/, проучвали района комп^ексно са Каре^ Шкорпи^, Асен Василиев, Стоян Йорданов (Skorpil, 1914), (Vasiliev, 1953), (Yordanov, 2009). Релица български и чужАи учени се занимават в прольлжение на Аесетилетия с особеностите на художественото и епиграфрското наследство. СреА тях може да откроим имена като Крьстю Миятев, Н. Аврамов, Анлрей Грабар, Габриел Мийе, Милко Бичев, Елка Бакалова, Велда Марли-Бабикова, Ара Маргос, Казимир Попконстантинов, Коста Халжиев, Аиляна Мавродинова, Боряна Аживлжанова и лр. (Bichev, 1965), (Bakalova, 1976), (Mardi-Babikova, 1980), (Margos, 1982), (Mavrodinova, 1989), (Duichev, 1983), (Angelov, 1962), (Andreev, 1975), (Bozhkov, 1985), (Mavrodinov, 1946), (Praskov, 1984). Осветляването на историческото и културно-историческото значение на средновековния манастирски комплекс както за среАновековната българска Аьржава, така и като значимо национално, общоевропейско и световно наслеАство са причина запазените стенописи в скалните храмовете при с. Иваново $а$ а бъАат вк^ючени в защитените обекти на световното материално културноисторическо наследство поА егидата на ЮНЕСКО. Районът е със статут на исторически резерват стопанисван и подАьржан от РИМ Русе. През всички ИзминаАИ гоАини САеА пореАица проучвания И описания осьществени в района са локализирани общо селем манастирски комплекса, пет от който са разположени на Аесния бряг на река Русенски ^ом, в скалната Аьга, в местността „Писмената“, редуващи се най-общо от запал на изток "Свето Преображение“/ т.н. „Белберница“, „Берберница"/, "Св Архангел михаил" / Затрупаната цьрква/,

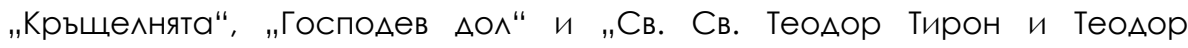
Стратилат" / "Сьборената цьрква"/. На левия бряг на реката са ^окализирани манастирските комплекси "Стьлбицата" и "Св. Богородица" /Цьрквата/, в който е елинствената запазена скална цьрква, 
която е с най-запазената и съхранена стенописна украса, което е предимството на този обект, $А$ б бьле еАинствения социализиран, отворен през топлото полугодие обект на русенския исторически музей, Аостьпен и предназначен за посещение от туристи.

През последните голини по инициатива на Евгени Коев, председател на пещерен клуб "Аервент" кьм ТА "Акалемик-ВтУ", спелеолозите от клуба и представители на Ученически спелеоклуб „Профр. Р.Попов" при ПГт „А-р Васил Берон“, гр. Велико Търново провеждат системни, цялостни проучвания в района на Ивановските скални манастири (Koev, 2016). След събиране на пьлната налична научна и научно-популярна инорормация за скалните манастири са проведени и поредица от теренни обхожАания за локализиране основните обекти в района, проучване и провежлане на експедиции за полробно картиране и Аокументиране на някой от манастирите. Благодарение на Аосегашните усилия Ао момента са проучени, описани и Аокументирани

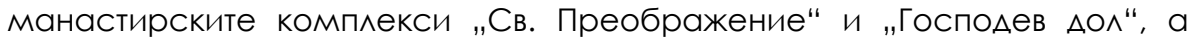
комплексите "Св. Богородица" и "Св. Св. Теодор Тирон и Теодор Стратилат" са картирани и описани в по-голямата си част. Естествено послеАващите усилия за пьлното проучване на района $а$ а са насочени към цялостното изслеАване на най-мащабните манастирски комплекси "Св. Архангел Михаил“ и „Кръщелнята"

В началото на месец февруари 2020 гол. се проведе поредната теренна експедиция на търновските пещерняци в района на Ивановските скални манастири. Основните, предварително заложени цели на експедицията са - осъществяване на теренни, Аистанционни и преки наб^юдения в малко проучвани или непроучвани от екипа участъци от комплекса. Район за обхожлане за конкретната експелиция е опрелелен участька в основата на скалния венец в района на Авата найголеми, непроучвани от екипа манастирски комплекси. ОбхожАането и Аетайлното проучване на планираните участъци от преАставители на клуба в поАножието на скалния венец около манастирския комплекс „Кръщелнята" АовеАоха Ао интересни открития. При проучването, Евгени Коев с изненала попала на неспоменавана $А$ този момент скална цьрква с прилежащи към нея грубо оформени скални килии. При конкретното проучване за деня предвил пьрвоначално поставените цели и материална осигуреност свързана с тях, се осъществява еАинствено по-пьлно фотозаснемане на обекта с акцент на някой конкретни детайли. СлеАвайки възприетия принцип при теренни проучвания слеА 
направените наблюдения на терен се пристьпва кьм проверка на наличната инорормация за района и конкретния участьк, при която се установява категорично, че новолокализирания обект въпреки Аългогодишните проучвания от различни изслеАователи, същият Ао този момент не е регистриран и описван.

Конкретният обект, слеА Аопьлнително проучване свеАенията и описанията на обекти в района, се оказва, че не само не е описан, но Аори не е споменаван от никой от Аосегашните изследователи на Ивановските скални цьркви и манастири. Още при пьрвото наблюдение е установено и заснето, че скалната цьрква се намира в най-ниското, приземно ниво от Аостигащия четири етажа с полуетажи скален комплекс "Крьщелнята", като заема неговата ниска източна окрайнина, което е още енна интересна особеност за обекта, защото всички останали скални храмове, Аори и параклисите, са разположени на определена височина в скалните венци. Пьрвоначалните впечатления са, че църквата е с изключително старателно оформена и обработена източна част с изсечена характерна абсила в североизточна посока, заместваща светият престол в скалните цьркви и протезисна ниша, разположена канонично на северната олтарна стена на храма, която свилетелства, че в новооткритата скална цьрква са извършвани всички възможни богослужения, вкАючително и Аитургии. ИзкАючително старателната обработка и заглажАане на източната стена и източната част на пола и тавана в олтарното пространство и неуглеАното, грубо одрормено пространство в запалната половина на цьрквата контрастират и показват различно ниво на обработка и офрорммение, но и подчертават отношението към „божественото“ и „послушническото отшелническото" пространство в храма. На този общ архитектурен и художествен вил на храма, интерес представлява още еАин елемент от скалния храм, изсеченият в запалната стена или по-скоро в северозапалния ьгъл "влаАишки трон" С интересно изсечена грубо офрормена, но ясно мичаща си, офрормена полусорерично, плитка, но обемна като ширина и височина скална ниша в основата, в среАната част, на която е разположен трона, наА който „нишата“ офрормя своеобразен ореол, който затвьржАава еАна от работните хипотези на изследователите за архитектурата на скалните храмове в този район.

За детайлното проучване, локализиране и картиране на новооткритата скална цьрква се провеАоха Аопьлнителни теренни проучвания в края на месец август, на 26.08.2020 гол. И в началото на месец септември, на 13.09.2020 гол. Скалната цьрква, се оказа с 
приблизителни размери от 2.5 метра ширина, 4 метра Аьлжина и около 2 м. височина При полробното проучване и документиране на скалната цьрква се осъществи картиране и заснемане и на при^ежащите кьм нея скални ниши, които най-вероятно са преАставлявали в миналото Монашески КИАиИ.

При точното ^окализиране на обекта с GPS устройство Garmin Etrex 30, приемащо еАновременно сигнали за наземно позициониране от системата GPS и от системата GLONASS с точност на позициониране 3 M. се установи, че същият е разположен на височина наА морето на 64

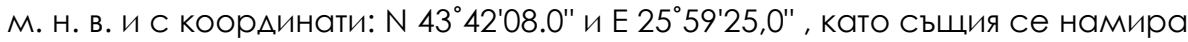
на около 100 М. Източно от гАавния поАХоА КъМ Комплекса „Крьщелнята“, в самото полножие на съвременния скален венец.

При летайлното картиране на обекта се установиха точните размери на скалната цьрква, от 4.80 м Аьлжина и 1.95 м ширина с вероятен отстьп на вьтрешната ширина от още около 30-40 см, а изцяло, АО вьншния край на скалната козирка $А$ о 2.90 М. Вхольт кьм храма е решен нетрадиционно, в югоизточната част, което поставя редица вьпроси, но както и при някой Аруги скални цьркви, каквито примери има и при този случай явно при оорормяне на храмовото пространство, изгражАалите скалната цьрква са съобразили и подчинили общото архитектурно решение с особеностите и предварителното естествено офрормление на сьществуващата скална ниша. За елно такова мнение по отношение офрормлението на храма полсказва и сравнително голямото отклонение на главната ос на Аьлжината на храма и ситуирането на олтарното пространство с олтарната ниша, ориентирани на 50 , с тралиционното източно ориентиране на православните храмове от близко $А$ $90^{\circ}$ в рамките на еАно Аопустимо откАонение от по около $20^{\circ}-25^{\circ}$, което при конкретния случай е многократно наАвишено. В същото време отклонението е обяснимо, преАвиА местоположението на скалния храм в основата на скалния венец извисяващ се на повече от нал $80 \mathrm{M}$ височина и липса на възможност за точно ориентиране и опрелеляне на посоките на света чрез използване на приролни ориентири на конкретното място, като в същото време изграждащите храма е трябвало $\Delta а$ се съобразяват и с наложените природни условия и $\triangle$ ААености от скални ниши.

Олтарното пространство на скалната цьрква впечатлява с изключително старателното офрормление, елегантност при офрормяне на олтарната абсила, старателно заглажАане на частите от поАа, стените и 
тавана, точното и хармонично разположение и старателно офрормените, с точни размери на изсечените скални ниши изАьлбани за свети престол и за приношение при извършване на светите тайнства по време на православната служба. Размерите на олтарното пространство е 1.95 м ширина / С3 - ЮИ/ и 1.40 м Аьлбочина /ЮЗ - СИ/

В Североизточна посока / СИ, която условно, за улобство по-Аолу ще наричаме източна - И /, на височина от 1.02 м наА пола е старателно изАялана олтарна ниша с ширина 76 см, 82 см височина и 36 см Аьлбочина. На северозапалната стена /СЗ стена, която за удобство условно ще наречем по- олу запална - 3/, на височината на олтарната ниша е прецизно одрормена протесисна ниша с размери 60 см ширина, 60 см височина и 20 см Аьлбочина. МежАу Авете основни ниши, на по-ниско ниво, на 80 см наА пола има АОПьлнитеАно оформена още еАна малка ниша С размери 18 см ширина и 20 см височина и Аьлбочина, вероятно служеща по време на използване на храма за съхранение на част от богослужебните съсьАи или Аруги вещи с богослужебно преАназначение. Ha пола на северозапалния край на олтара на около 20 см запално поА запалния край на протесисната ниша съществува вкопан в пола жлеб с приблизително квадратна фоорма със страна 5 см, който явно е бил оорормен за прикрепване на съществувалия в миналото иконостас отАелящ олтарното пространство от наоса на храма. Съществуващото в северната половина на олтарното пространство по-високо ниво но пода, Аава основание $а$ а се Аопусне, че в миналото в храма е била одрормена и солея С височина от ОК. 10 см. (Фиг. 1).

Освен Аобре офрормените пространства и ниши в олтарната част на храма, впечатление прави арковилно изсечената плитка ниша с Аьлбочина от около 20 см в северозапалния ьгьл на храма офрормяща сравнително просторно пространство с размери в основата си на запалната стена от 1.04M и на северната стена 1.16м Аь^жина, в което е офрормен скален престол със сеАало на височина от 0,5м от пола и Аьлбочина от около 40 см, изпьлняващ в миналото най-вероятно функциите на влалишки трон, който макар и обрушен в настоящия момент, Аава представа за съществувалите размери и орорма. Необичайното за Анес местоположение на влалишкия трон може $а$ а се обясни с ранната практика на разположение на този елемент от храмовото пространство. СлеА въвежлането на иконостасите, пьрвоначално архиерейските тронове са били разположени от ^яво на солеята, срещу влалетелския трон, който е бил разположен срещуположно от Аясната страна, като в случая малкото пространство 
на скалната цьрква и съобразяване с условията е Аало възможност за одрормянето на влалишкия трон не на северната стена, а в северозапалния ьгьл на храма. Въпреки копрометирането на тази част от храма и известно обрушаване поради съществуващи естествени пукнатини на скалата, то обяснението на това място, като в^алишки трон, а не само като Аруг схолен елемент от устройството на храма произтича и от общото офрормление с Аобре оформената арковинна орорма в тази част на скалната цьрква, която я прави в известен смисьл поособена като офрормление, а вероятно и като функция, каквато е имала при нейното активно функциониране.

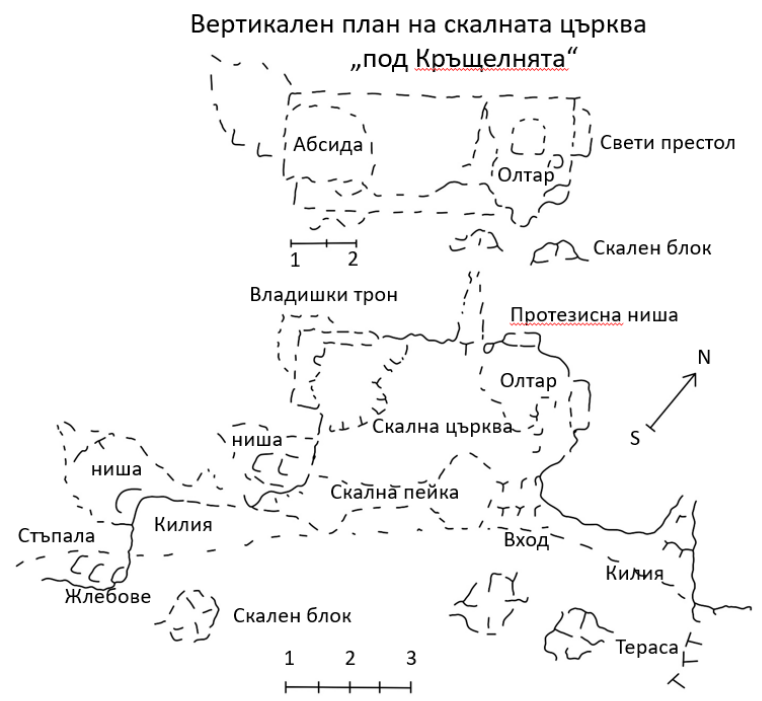

Хоризонтален план на скалната църква и прилежащи килии

\section{Фиг 1. Вертикален и хоризонтален план на скалната църква и прилежащи килии}

Южната прегранна стена на храма, каквато без сьмнение е съществувала в миналото, към момента не можа $а$ б бъле определена като местоположение. Като се има предвил съществуващата коноригурация и нива на терена на пола, може $\Delta$ a ce $\Delta$ опусне, че тази преграла е била от външната страна на съществуващото нал^ъжно изАигане на нивото на пода от материковата скала, което е възможно $А а$ е офрормяло скална пейка с размери около 2.50 м Аължина, около $40 \mathrm{~cm}$ височина и около 30 см Аьлбочина на селалото. В запалния край на 


\section{ЕВГЕНИ КОЕВ}

продьлжението на южната сена, в естествено съществувала скална ниша ясно ^ичат изкуствено офрормените ^егла за греди или малки ниши вероятно С някакво помощно предназначение за съхранение на вещи или Аруго полобно преАназначение (Вж. Приложение с фоигури).

Югозапално от храма, буквално прилепена $А$ неговия ьгьл съществува сравнително правилен скален ьґьл, частично защитен от скална козирка в който съществуват всичания, поАсказващи наличието в миналото на Аьрвена конструкция оформяща вероятно монашеска килия с размери 2.85 м Аьлжина и 1.50м ширина. В югозапалния горен край на скалната стена мичат Аобре офрормени стьпки за закрепване на съществувалите в миналото Аьрвени греди. В северозапалния ьгьл на Около 1.20 м наА нивото на земята в естествено съществувала скална ниша, стьпаловиАно са офрормени заравнености полсказващи вероятното предназначение на този кът за съхранение на предмети с битово или богослужебно преАназначение.

По продьлжение на основата на скалния венец в източна посока, съществува още еАин скален ьгьл, този със стени от север и изток, при който е съществувало още еАно по-малко помещение, също одрормено чрез използване на скалния заслон и Аоофоормено чрез Аьрвена конструкция. По продьлжение на неговия източен край в южна посока съществува и Анес скална площаАка /тераса/ с ниво от около 70 См нал продьлжаващата на изток основа на скалния венец. Новооткритата скална цьрква с прилежащите към нея килии оорормят еАна специфрична част от Аолната окрайнина на еАин от най-обхватните манастирски скални комплекси. Самият храм, неговото местоположение, оформление и архитектурни Аетайли поставят еАна пореАица от въпроси, отговорите на някой от които могат $\Delta а$ Аалат еАна нова светлина при възстановката на манастирския скален комплекс и изобщо за храмовото строителство в Поломието. Цялостното проучване на обекта е прольлжение на проучванията в района на Ивановските скални манастири, които имат за цел изясняване в пьлнота на цялостната картина на най-голямото монашеско поселение в скални обители по нашите земи. 


\section{ПРИ^ОЖЕНИЕ:}
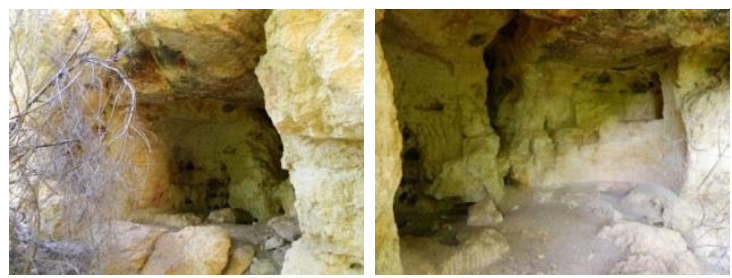

Фиг.2. Скална цьрква - общ виА

Фиг.3. Скална църква - вътрешен виА
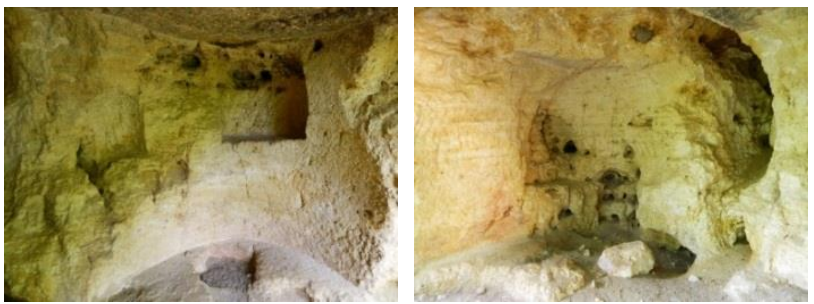

Фиг.4. О^тарна част

Фиг.5. Северозапална част
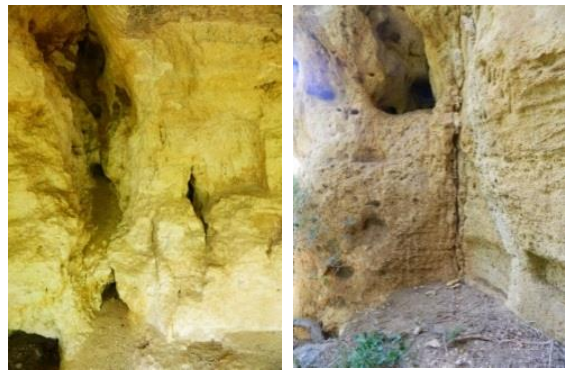

Фиг. 6. Протниша и жлеб за иконостас Фиг. 7. Запална ки^ия - общ виА

\section{AИTEPATYPA / REFERENCES}

Andreev, J. (1975). The inscriptions at ivanovo, Rusenski District, and the last years of the life of Tsar Georgi Terter ,l,-Centuries, 1975, book 3, pp. 77-85, // [АнАреев, Й. Налписите при с. Иваново, Русенски окрьг, и послеАните години от живота на цар Георги Тертер ,I,-Векове, 1975, кн 3, с 77-85]

Angelov, N. (1962). To the history of the rock monastery at ivanovo - Archaeology, 1962, book 3, рр. 45-51, // [Ангелов, Н. Кьм историята на скалния манастир при с.Иваново - Археология, 1962, кн 3, с.45-51] 
Bakalova, E. (1976). Ivanovo frescoes and ideas of isihazma - Art, 1976, book 9, pp. 1421, // [Бакалова, Е. Ивановските стенописи и илеите на исихазма - Изкуство, $1976, \mathrm{KH} 9, \mathrm{C.} 14-21]$

Bichev, M. (1965). The frescoes in Ivanovo, Sofia, 1965, // [Бичев, М. Стенописите в Иваново, София, 1965]

Bozhkov, A. (1985). Tarnovo Medieval Art School, Sofia, 1985 // [Божков, A. Тьрновската средновековна художествена школа, Софрия, 1985]

Duichev, I. (1983). Ivanovo - asleep cultural hearth of medieval Bulgaria. In: Pages of the Past, Sofia, 1983, pp. 286-295, // [Ауйчев, И. Иваново - заспало културно огнище на средновековна Бьлгария. В: Страници от миналото, Софиия, 1983, C. 286-295]

Koev, Ev. (2016). New Discoveries Related to Ivanovo Rock Monastery, Science series Cultural and Historical Heritage: Preservation, Presentation, Digitalization, volume 2, issue 1, pp. 91-99 // [Коев, Ев. Нови открития, свьрзани с Ивановските скални манастири, КИН, опазване, представяне, Аигитализация, В.Тьрново, 2016, Т 2, бр 1, с 91-99]

Mardi-Babikova, V. (1980). Ivanovo - a unique complex of frescoes from the Tarnovo School of Art. - Centuries, 1980, book 5, p. 547 // [Мараи-Бабикова,В. Иваново уникален комплекс на стенописите от Търновската художествена школа. Векове, 1980, кН. 5, с. 547]

Margos, A. (1982). For the inscriptions related to Tsar Georgi Terter I at the town of Ivanovo, Rousse. - 1982, book 4, pp. 44-50 // [Маргос, А. За налписите, свьрзани с цар Георги Тертер I при с. Иваново, Русенско. - Palaeobulgaricaq 1982, KH.4, C. 44-50]

Mavrodinov, N. (1946). StaroBulgarian Painting, Sofia, 1946, // [Мавродинов, Н. Старобьлгарска живопис, София, 1946]

Mavrodinova, L. (1989). Cave zerkvi in the villages of Ivanovo. C:Bolgari In Peace Cultural Heritage, Sofia, 1989, р. 169-192 // [Мавродинова, А. Пещерные церкви у села Иваново. В:Вклал Болгарии в мировое културное наслелие, Софиия, 1989, C.169-192]

Praskov, L. (1984). About the Tarnovo picturesque school and the chronology of its monuments from the end of the XII to the end of the 15th century. In: 1300 years bulgarian fine art, Sofia, 1984, pp. 41-49 // [Прашков, ^. За тьрновската живописна школа и хронологията на нейните паметницици от края на XII АO края на XVІв. В: 1300 голини българско изобразително изкуство , Сосрия, 1984, C. 41-49]

Skorpil, K. (1914). Inventory of antiquities along the Rusenski Lom River, Sofia, 1914 // [Шкорпи^, К. Опис на старините по поречието на река Русенски ^ом, Сосрия, 1914]

Vasiliev, А. (1953). Ivanovo Frescoes, Sofia, 1953, // [Василиев, А. Ивановските стенописи, Сосиия, 1953]

Yordanov, S. (2009). The Rock Monastery "St. Archangel Michael" at ivanovo. Publisher: "Slavena", Varna, 2009, // [Йораанов, С. Скалният манастир „Свети Архангел Михаил“ при с. Иваново. Иза. "САавена“, Варна, 2009] 


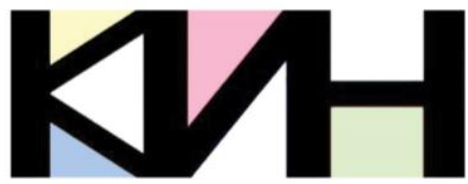

КУАТУРНО-ИСТОРИЧЕСКО НАСАЕАСТВО:

ОПАЗВАНЕ, ПРЕАСТАВЯНЕ, АИГИТААИЗАЦИЯ

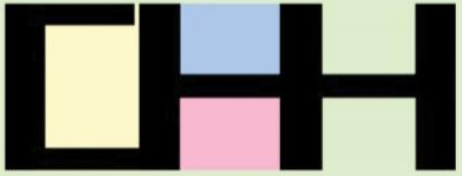

CULTURAL AND HISTORICAL HERITAGE: PRESERVATION, PRESENTATION, DIGITIZATION
Материалите в сборника са обект на авторско право. Разрешава се безвъзмезАното ползване на техни електронни/ хартиени копия само за лична употреба или обучение, при пь^но цитиране на текущата страница и слеА писмена декларация от цитиращия за мипса на търговски намерения.

(с) Авторски колектив, 2020

Техническо реАактори: Калина Сотирова-Вълкова Николай Ноев Паска^ Пиперков

\section{Editors}

Petko St. Petkov

Galina Bogdanova

This work is subject to copyright. Open and free of charge use of digital/hard copies of publications is granted only for personal or educational use, with full citation of the current page, and after written declaration of the quoting side for notcommercial Intention.

(C) Authors` Group, 2020

Technical editors:

Kalina Sotirova-Valkova

Nikolay Noev

Paskal Piperkov

НАЦИА регистрационен № 1209

Научна пореАица: том 6, брой 2 (9)/2020

Science series: vol. 6 , issue $2(9) / 2020$

NCID Registry No. 1209

www.math.bas.bg/vt/kin

ISSN: 2367-8038 